\title{
Goebbels' pegefinger og perspektivets præcision
}

\section{Om Marcel Beyers Flyvende Hunde}

Når man skal vælge bøger til en forelæsningsrække om moderne romaner, vil de store og kendte navne nærmest automatisk dominere. I forbindelse med den tyske litteratur efter 1945 kunne man eksempelvis tænke på Günther Grass, Martin Walser, Botho Strauss og måske Hans Magnus Enzensberger. Men siden 90'erne har man kunnet observere et generationsskift på den litterære scene i Tyskland. Skønt nogle af de gamle herrer stadig er til stede og i en vis forstand dominerende, er de ikke længere alene om at stå for den litterære udvikling og den æstetiske fornyelse. Fornyelsen skyldes snarere en ny generation af forfattere såsom Judith Hermann, Julia Franck, Christoph Peters, Zoë Jenny, Karen Duve og Thomas Brussig, der har opnået stor opmærksomhed i de tyske medier. Som en kritiker skrev om Judith Hermanns debutbog, er det nu 68'ernes børn, der tager ordet og afgrænser sig over for den dominerende tradition i den tyske efterkrigslitteratur.

Jeg skal her præsentere et af de nye navne. Marcel Beyer, født 1965, vakte allerede opmærksomhed med sin debutbog, Das Menschenfleisch (Menneskekødet) fra 1991, der fra en sprogteoretisk tilgang fortalte historien om kærlighed og jalousi på en ny og sofistikeret måde. Men først hans anden romanudgivelse, Flughunde (Flyvende hunde) fra 1995, blev hans egentlige litterære gennembrud. Romanen om en akustiker i nazisternes tjeneste blev hyldet i alle tyske medier og kan betegnes som den store litterære overraskelse i midt-90' erne. ${ }^{1}$ Med denne roman, skriver eksempelvis anmelderen Walter Hinck, stiller Beyer sig »endegyldigt i den første række af vores yngre forfattere«. ${ }^{2} \mathrm{Og}$ den indflydelsesrige kritiker Helmuth Karassek under-

1. Marcel Beyer: Das Menschenfleisch, Frankfurt a.M. 1991 (herefter forkortet M); Flughunde, Frankfurt a.M 1995 (herefter forkortet F); dansk oversættelse af Birgitte Brix: Flyvende Hunde, København 1997 (herefter forkortet FH). 
streger, at romanen for ham er »en af de mest imponerende bøger om de sidste krigsdage «. ${ }^{3}$ Den overvældende succes har ført til flere litterære priser og oversættelser til flere europæiske sprog.

I det følgende vil jeg læse romanen ud fra to tilgangsvinkler: På den ene side vil jeg prøve at følge Beyers diskussion af sproget og dets totalitære propagandavirkning som en indholdsdimension i romanen; for det andet vil jeg prøve at læse romanen som et eksemplarisk opgør med store dele af den tyske efterkrigslitteratur, især med de litterære traditioner som havde været dominerende i den forrige generation.

\section{I.}

Beyers roman handler om nazitiden, men dens tema er ikke begrænset til denne periode. Beyer forbinder snarere de historiske begivenheder med sprogteoretiske overvejelser og med en diskussion af forholdet mellem stemme og krop. Efter bogens andet kapitel skiftes to personer til at fungere som fortæller. Den ene er Helga Goebbels, propagandaministeren Joseph Goebbels' ældste datter, som i maj 1945 blev slået ihjel af sine forældre sammen med sine fem søskende, kort inden russerne besatte den såkaldte førerbunker i midten af Berlin. Den anden fortællerstemme tilhører Hermann Karnau, der ligeledes er en historisk person. Han indgik i førerbunkerens vagtpersonale og var en af de allieredes første vidner om Hitlers død. I romanen optræder han først og fremmest som akustiker og tekniker. Karnau er blandt andet ansvarlig for de tekniske forberedelser til de store propagandamøder, hvor han indstiller højttalere og mikrofoner, så nazisternes taler kan udfolde hele deres propagandavirkning. Senere i romanen arbejder han ved fronten i Frankrig hvor han optager fjendens radiosignaler og hjælper med den såkaldte "affranskning« af Elsass-området. Og endnu senere kommer Karnau til at arbejde sammen med dr. Stumpfecker - en figur der bygger på den berygtede SS-læge dr. Stumpfegger - i et SS-forskningsprojekt der indebefatter menneskeforsøg. Til sidst optræder han i førerbunkeren i Berlin i krigens sidste dage.

Helga Goebbels og Hermann Karnau mødes kun to gange inden deres veje senere krydses i førerbunkeren. Deres første møde finder sted i andet kapitel, hvor læseren for første gang bliver præsenteret for Helga Goebbels' stemme. Karnau, som gennem sit arbejde har omgang med Joseph Goebbels,

2. Walter Hinck: "Das Röcheln der Rührung. Marcel Beyer betrachtet 'Flughunde'», in Frankfurter Allgemeine Zeitung, den 11. april 1995.

3. Helmuth Karassek i fjernsynudsendelsen »Das literarische Quartett«. 
passer her børnene, mens Marta Goebbels venter sit sjette barn på hospitalet. Derefter mødes de to fortællere kun en enkelt gang til et selskab hos Joseph Goebbels.

Der findes dog en tematisk sammenhæng mellem de to fortællere, i kraft af stemmens motiv. Allerede ved deres første møde bliver vi præsenteret for Karnaus store lidenskab for stemmer, som han også beskæftiger sig med privat, i og med at han efter arbejde forsøger at »opspore stemmens hemmelighed« (FH, p. 48). Baggrunden for hans søgen er den klassiske antagelse om, at den menneskelige stemme udgør forbindelsen mellem det indre og det ydre. Med Karnaus ord: »Ikke så mærkeligt at man mener, at dette uhåndgribelige noget, der kaldes sjælen, kan lokaliseres i den menneskelige stemme. Formet åndedrag, åndepust: Det, hvoraf mennesket består« $(F H$, p. 21).

Karnaus søgen efter stemmens hemmelighed rummer altså et forsøg på at finde menneskets væsen. At dette væsen kan lokaliseres i den menneskelige stemme, er inden for den moderne franske filosofi blevet beskrevet som en idé om den umiddelbare præsens, der ifølge Jacques Derrida kan karakteriseres som phonocentrisme, hvor "stemmen som skaber af det første tegn væsentligt og umiddelbart er beslægtet med sjælen«. ${ }^{4}$ Karnaus opfattelse af stemmen skal læses i denne traditionslinie. Men samtidig er ideen om den umiddelbare præsens blevet problematisk for akustikeren og teknikeren Karnau, der er i stand til at optage stemmerne på bånd eller grammofon og således høre sin egen stemme forskudt i tid. Senere i romanen hedder det med henvisning til Edisons opfindelse af fonografen i 1877: „Efter at de første ord var indridset i tonevalserne, kunne de talende følge dem tidsmæssigt forskudt uden at danne lydene en gang til: Det første menneske kunne lytte til sig selv«(FH, p. 161). Og også Karnau har hørt sig selv som barn. Han husker: »Det er meget længe siden, jeg første gang mødte min egen stemme, måske var det som barn, jeg hørte den for første gang uden at tale samtidigt« $(F H$, p. 58). I det selskab hvor stemmerne blev optaget på fonografen, kunne Karnau dog ikke umiddelbart genkende sin egen stemme, da vokspladen blev afspillet: »Det varede et øjeblik inden det gik op for mig, at det kun kunne være mig selv. Lyden i mit eget hovedet var imidlertid en helt anden end denne barnlige stemme: Den dag i dag forekommer den lyd, som overføres fra mine knogler til min hørelse, mig dybere og varmere end de lyde, der baner sig vej udefra til øret. Jeg var forfærdet«(FH, p. 59). Stemmen som stedet for den menneskelige præsens er således blevet problematisk med de nye mediers tekniske muligheder.

4. Jacques Derrida: De la grammatologie, Paris 1967, p. $21 \mathrm{f}$. 
Den materielle opmagasinering af lyd kan med Friedrich Kittler - som Beyer tydeligvis er meget inspireret af - læses som et paradigmeskift i opfattelsen af menneskene og sproget. Havde man omkring 1800 formodet, at der i stemmen viser sig en transcendental substans, så bliver denne tanke om et menneskeligt væsen og en transcendental signifié med den nye teknik "undergravet af en ubedragelig positivitet «. ${ }^{5}$ Fonografen, mener Kittler, »opmagasinerer en dødelig stemme i stedet for evige tanker og ordforbindelser.« Den indebærer således, at mennesket kan reduceres til en fysiologisk lyd, som optages på bånd eller voksplader. I forbindelse med sprogteorien betyder det ifølge Kittler: „Grammofonen tømmer ordene ved at konfrontere deres imaginære side (signifié) med en real side (stemmefysiologi)«. ${ }^{6}$ Den nye teknik ophæver således antagelsen om den umiddelbare præsens og erstatter den indre og imaginære forbindelse mellem signifiant og signifié med »en skrift uden skrivende ${ }^{7}{ }^{7}$ Ifølge Kittler bliver sprogets paradigmatiske akse med andre ord negeret til fordel for den syntagmatiske akse.

Karnaus søgen efter stemmens hemmelighed kan læses på denne teoretiske baggrund. I modsætning til Kittler accepterer Karnau dog ikke paradigmeskiftet; han fortsætter snarere sin søgen efter det ægte bag den stemme, der nu kan optages med de nye medier. Erfaringen af at stemmen ikke svarer til det som man troede, tolker han således ikke som et vidnesbyrd om umuligheden af at finde menneskets væsen bag ved stemmen; for Karnau bliver det snarere en bevæggrund til at opspore stemmens hemmelighed, til at søge det ægte og oprindelige bag stemmen. ${ }^{8}$

5. Friedrich A. Kittler: Aufschreibesysteme 1800 - 1900, München 1987 (anden, udvidede udgave), p. 242.

6. Ibid., p. 252.

7. Ibid., p. 323 .

8. Kritikeren Thomas Schmidt skriver således om Karnau: „Stemmen er for ham netop ikke differensens kropslige signal, men derimod tegnet på det første, det ægte, det oprindelige. Og søgningen efter dette [...] gør ham til en dæmon«, Thomas E. Schmidt: »Erlauschte Vergangenheit. Über den literarischen Stimmensucher Marcel Beyer«, in Thomas Kraft (udg.): aufgerissen. Zur Literatur der 90er, München 2000, pp. 141-150, her p. 150. Både i Das Menschenfleisch og i Flughunde bliver denne direkte tilgang til det oprindelige symboliseret med Rilkes "Ur-Geräusch«, hvor hovedet hører sig selv når "die Schädelnaht« (hjerneskalsnålen) ( $M$, p. 129) bruges som medium for en pladespiller. Hverken den anonyme fortæller i Das Menschenfleisch eller Hermann Karnau er dog i stand til at finde denne »Ur-Geräusch«; hos Karnau bliver drømmen snarere et mareridt (se $M$, pp. 128f; $F H$, pp. 223ff; se også Kittler, op.cit., p. 32lff.). I et interview har Beyer senere udtalt at begge stemmer søger efter den "uformidlede kommunikation" som ligger hinsides sprogets konventioner. Med henvisning til sin romandebut sagde Beyer: „jeg ved at det ikke er muligt, og begge figurer i Das Menschenfleisch og Flughunde ved det egentlig også godt. Alligevel forsøger de desto voldsommere at finde den direkte kommunikation. Ligesom bas-boxen på et Sound System kommunikerer med mine tarme uden at tage omvejen omkring nogen som helst betydning - det er sådan noget som figurerne søger efter i forholdet til andre mennesker«, Martin Pesch: »Wo Klang und Inhalt aufeinanderkrachen. Der Schriftsteller Marcel Beyer im Sound der Dub-Musik: eine Annäherung", in Frankfurter Rundschau, den 8. August 1998. 
Karnaus søgen efter stemmens hemmelighed foregår på to måder. For det første overvejer Karnau allerede, da han erfarer, at den optagede stemme ikke svarer til det indre, hvordan stemmen kan påvirkes udefra. Han mener således, "at stemmen må kunne lade sig forme, den må kunne bringes i overensstemmelse med den indre hjerneklang gennem øvelser, gennem den opmærksomme håndtering af strubehoved, tunge, brystkasse og svælg allerede inden talen. Man må der kunne få krammet på det, dette organ, som alle fremmede kan høre, denne forbindelse indefra og ud, som et menneskes tunge blotlægger mere end nogen anden bevægelse« $(F H$, p. 59). Bag ved denne harmløse intention antydes allerede Karnaus diabolske projekt. Stikordet er her tungen og strubehovedet. Eftersom stemmen for Karnau er forbindelsen mellem det indre og det ydre, må taleorganerne være det sted, hvor det indre manifesteres i kroppen. Strubehovedet bliver til det reale objekt, hvor menneskets historie og væsen kan spores. ${ }^{9}$

Drømmen om at finde menneskets historie og ægthed bag stemmen får Karnau til at begynde at dissekere dyrehoveder, som han har købt hos slagteren for at undersøge taleorganerne. Hans udgangspunktet er en erfaring af, at bøgerne om og de skematiske tegninger af disse organer »intet [røber] af hemmeligheden ved levende lyde« $(F H$, p. 48). Karnau konkluderer derfor: "Jeg havde ikke anden udvej end at fortsætte mine studier på selve genstanden« $(F H$, p. 48). Til sine undersøgelser af hoveder fra døde okser, får og heste bruger Karnau blandt andet brødkniv, saks og strikkepind som værktøj, og »af og til også en gammel spade, når hovedet er særligt svært at få hul på« $(F H$, p. 50$)$. Hans videnskabelige passion bliver til en konkret medicinsk indgriben i taleorganerne: "Med kartoffelskrælleren får man for eksempel uden besvær trukket hovedhuden af. I det mindste kommer man på denne måde måske lag for lag hemmeligheden nærmere, selv om man ikke vil kunne afsløre den« $(F H$, p. 50$)$. Med disse indgreb er vejen banet for Karnau. Det, som starter med dyrehoveder, vil senere i romanen få ham til at skære i levende KZ-fanger under opsigt af dr. Stumpfecker og til sidst gøre ham medskyldig i de seks Goebbels-børns død.

Karnaus anden måde at søge stemmens hemmelighed på består i hans ambition om at registrere alle menneskelige lyde og stemmer, som han vil indføre på en slags kort eller atlas: „Et kort, hvorpå selv de mest usanselige lyde skal noteres: For eksempel denne heftige frempressen af luft mellem

9. Med Karnaus ord: „Vi har alle ar på stemmebåndene. De dannes i livets løb og enhver ytring fra spædebarnets første skrig efterlader spor. Hver host, hvert skrig, al hæs tale skæmmer stemmebåndende yderligere med et snit, en forhøjning eller stribe. [...] Arrene på stemmebåndende danner således en fortegnelse over tungvejende oplevelser, akustiske udbrud, men også tavshed. Hvis bare man kunne afsøge dem med fingeren, med deres spor, holdepunkter og forgreninger. Dér, i strubehovedets mørke: Det er din egen historie, som du ikke kan udgranske«, $F H$, p. 21. 
slappe læber, som en del rygere praktiserer« $(F H$, p. 27$)$. Vi vil se, hvordan denne måde at opspore stemmens hemmelighed på senere forbinder sig med de medicinske indgreb. Men i første omgang nøjes Karnau med at optage de menneskelige lyde på grammofonplader og magnetbånd, som lige er kommet frem som ny teknik. Dette fører blandt andet Karnau til fronten hvor han helt uden følelser optager de døende soldaters lyde, og til Elsass-området hvor nazisterne er i fuld gang med at ensrette sproget ved at forbyde den lokale befolkning at tale fransk. Menneskene er for ham kun materiale til hans undersøgelser - »lydkilder«, som Karnau siger (FH, p. 29). „Mine arbejdsbetingelser her i Elsass er fremragende. Af de utallige optagelser, der foretages, mærker jeg mig de mest interessante, så at jeg om aftenen efter fyraften kan kopiere dem til personlig brug« $(F H$, p. 83). Men dermed deltager Karnau i nazisternes terror og »hensynsløse razziaer«, der bygger på hans optagelser: „Dér står jeg med mit apparatur midt i en skare grædende børn, hvis fædre er blevet afhentet af affranskerne. Kun på grund af en stemmeoptegnelse, som jeg har foretaget. Og mikrofoner, optagelser i skrifteskole, hvor folk stadig godt tør tale fransk med præsten. Den, kirken, bliver så stormet« $(F H$, p. 83f $)$.

De nye tekniske medier kan således ikke kun bruges i hans private projekt, men også i bestræbelsen på at ensrette menneskenes stemmer, på at »kontrollere stemmer", som Karnau kalder det med henblik på opfindelsen af fonografen ( $F H$, p. 161). Og også her er Beyer påvirket af Kittlers medieteori. Ifølge Kittler bliver menneskene beregnelige, i og med at de nye medier kan fastholde og kortlægge stemmen som menneskets fysiologiske og materielle udtryk: »Man kan opmagasinere menneskets stemme, dets fingeraftryk, dets fejl [...] Edisons staniolspoler og Galtons fingeraftryksarkiver er bevidst udtænkte skriftbærere for data, som hverken kunne opmagasineres eller bedømmes uden maskiner. ${ }^{10}$ Med henblik på opfindelsen af fonografen skriver Kittler: "Når fonografen [...] tvinger den talende til at sige noget skjult, fungerer den som en fælde. De bliver identificeret, ikke symbolsk, som gennem navnet, ikke imaginært, som gennem det romantiske helt-læserforhold, men realt." ${ }^{11}$ På denne baggrund stiller Kittler diagnosen: »Menneskets død og sikringen af kroppens spor er én og samme ting [...]. På denne næsten kapillære kontrol går individet fra 1800 til grunde. ${ }^{12}$

Karnaus lidenskab for stemmer er således alt andet end uskyldig. Hans private søgen efter stemmens hemmelighed og menneskets væsen bliver snarere del i et projekt om at fiksere og ensrette menneskene. Og netop

10. Kittler, op.cit., p. 243.

11. Ibid., p. 242.

12. Ibid., p. 243. 
denne længsel fører ham til nævnte menneskeforsøg. I en videnskabelig tale om sine stemmeoptagelser og sine erfaringer fra Elsass vender Karnau sig imod nazisternes »sprogreguleringer, udslettelse af utyske ord ", "sprogøvelser i kor, fællessange« og »SA’s monotone talekor", som ifølge Karnau »intet [ændrer] i kernen« (FH, p. 136). Mod denne "indpakning udefra« opstiller Karnau sin egen strategi:

\begin{abstract}
"Allerførst må vi lære at lytte opmærksomt. For ikke alene sproget, også stemmen, samtlige menneskelige lyde må, når man først begynder på det, ensrettes. Vi må gribe hver enkelt, vi må trænge ind i menneskets indre, og dette indre ytrer sig som bekendt i stemmen, der udgør forbindelse fra det indre til det ydre. Ja, vi må afsøge menneskenes indre, idet vi iagttager stemmen yderst nøje [...]. Gribe det indre, idet vi griber fat i stemmen. Bearbejde den og i ekstreme tilfælde ikke engang vige tilbage for medicinske indgreb, for ændringer af det artikulatoriske apparat« (FH, p. 137).
\end{abstract}

Foredraget bliver blandt andet overværet af dr. Stumpfecker, som bagefter begejstret henvender sig til Karnau og overtaler ham til at deltage i et projekt om at udforske alle lyde og deres materielle betingelser i det artikulatoriske apparat - på levende KZ-fanger. At Karnau deltager i SS-forskningsgruppen skyldes mest, at han på denne måde slipper for at blive indkaldt til militærtjeneste. Og Beyer har senere i interviews understreget, at Karnau formentlig ville mene, at det er ham selv, der udnytter systemet, mens systemet i virkeligheden udnytter ham. ${ }^{13} \mathrm{Ud}$ fra romanens logik ser vi dog tydeligt, hvordan Beyer med Karnau-figuren tolker nationalsocialismen ud fra sprogteoretiske overvejelser. Hans søgen efter det reale og autentiske bliver sat i forbindelse med bestræbelsen på at identificere og ensrette menneskene. Ikke kun nazisternes totalitære sprogbrug i forbindelse med deres politiske propaganda, men også denne søgen efter det autentiske bag ved stemmen er et genuint totalitært projekt.

På denne baggrund er det tydeligt at Helga Goebbels har rollen som offer. Den danske anmelder Thomas Thurah skrev således at Beyer fremstiller de "gode overfor de onde, barnet overfor de voksne«. Med andre ord: "Til gengæld for menneskets forråelse idealiseres barnet«. ${ }^{14}$ Thurahs læsning af romanen bygger formentlig på udsagn af Karnau. Efter at have passet Goebbels' børn, reflekterer han blandt andet over deres stemmer: »I dag er stem-

13. Karnau ville desuden, mener Beyer, aldrig betegne sig selv som nationalsocialist; han er snarere "kommet med oppositionelle udtalelser«, "Spurenlesen. Marcel Beyer über Geschichte, die Sinne und Literatur«, in: Grauzone (TalkZone), februar 1998, p. 14.

14. Thomas Thurah: »Forhistorien«, in: Weekendavisen, april 1997. 
mebåndene stadig smidige, og børnene taler ganske utvunget. De er sikkert ikke engang den frihed bevidst, hvormed de danner ord og lyde« (FH, p. 74). Senere, mener Karnau, vil også børnene tabe deres uskyld, og stemmen vil "uvægerlig blive mindre naturlig« (FH, p. 74). Børnene bliver med tiden opdraget til at følge de voksnes sprogbrug, så de lærer »denne tøvende, denne usikre måde at tale på«, som voksne bruger, og "de vil slet ikke mere vide, at deres stemmer engang har været anderledes« $(F H$, p. 75). Opdragelsen bliver tolket som en normeringsproces, hvor børnene bliver skolet i de gældende regler og normer - en analyse der i forbindelse med nazitiden jo ikke er helt forkert.

Ud fra Karnaus perspektiv er barndommen således et frit rum som først senere tabes. Allerede i andet kapitel bliver dette sat i forbindelse med Karnaus stemmeoptagelser. Karnau overvejer, om der er grænser for hans kort over samtlige stemmenuancer, med andre ord: om der er optagelser som han »ikke ville gennemføre«. Svaret er: »Disse børns stemmer bliver ikke indtegnet på mit kort, hvor de ville være tilgængelige for alverden og, værre endnu, også for børnene selv« $(F H$, p. 62). Grunden er at børnenes stemmer ellers »krænger over i det krampagtige«, som ifølge Karnau »uvægerligt ville være følgen, da de fem børn jo måtte opleve deres egne stemmer som lige så fremmede, som jeg selv gjorde dengang som barn« $(F H$, p. 62). Hans forehavende holder dog ikke særlig længe. I førerbunkeren, i krigens sidste dage, optager han alligevel deres samtaler med en mikrofon skjult under sengen. Kort efter er børnene døde, uden at man nogensinde med sikkerhed har kunne opklare, hvem der hjalp Marta og Joseph Goebbels med at forgifte dem.

Mange år efter krigen, fortæller romanen, finder man et lydarkiv fra nazitiden i Dresden. Karnau, der stadig er i live, bliver tilkaldt, og man tager ham for en forhenværende vagtperson. Efter at have givet få enkle informationer om arkivet - dog uden at tilkendegive sin sande identitet - går han hjem og hører endnu engang de gamle optegnelser, blandt andet fra krigens sidste dage i førerbunkeren. Karnau opdager nu gamle optagelser med børnenes stemmer, blandt andet en voksplade uden dato som han ikke før har hørt. På trods af den dårlige kvalitet mener Karnau at genkende Helga Goebbels' stemme, og hendes sidste ord er: „Er det hr. Karnau, der kommer ind til os?«(FH, p. 293). Bagefter høres kun en mørk voksenstemme i baggrunden, en kvinde eller en mand der ligesom langt væk fra sukkende siger: »Ja, ja, åh ja» (FH, p. 293). Og så: »En slubrende lyd, der i alt gentages seks gange. [...] Så høres kun vejrtrækning. Seks børnelungers vejrtrækning i forskudt rytme. Intensiteten og lydstyrken aftager. Til sidst hører man slet ikke noget mere. Der hersker absolut stilhed, skønt nålen stadig ligger i rillen« 
(FH, p. 294). Karnau er øjensynlig ikke helt uskyldig i børnenes død - på mange måder.

Havde Adrian Leverkühn en længsel efter det mørkt romantiske der førte ham til nazisternes terror, så bliver Karnau på grund af sit faustiske projekt medskyldig i nazisternes terror og formentlig til sidst til morder.

\section{II.}

Den formale dimension i romanen skal ses i umiddelbar sammenhæng med det sprogteoretiske tema. For at undersøge dette, vil jeg i de følgende to afsnit se nærmere på to essays af Beyer der understreger hans sprogopfattelse og hans formale krav til litteraturen, netop i forbindelse med fremstillingen af nazitiden og holocaust. I et bidrag til antologien »Literatur und Holocaust« fra 1999 skriver Beyer således den næsten programmatiske sætning: "Holocaust som motiv, som noget der beskrives, som baggrund i et litterært arbejde træder frem som et formspørgsmål«. Beyer skynder sig dog i samme sætning at tilføje at dette intet har at gøre med »æsteticisme» eller med »formalisme som eskapisme« eller »hvordan det nu er kampbegreberne lyder ${ }^{15}{ }^{15}$

I den nævnte artikel diskuterer Beyer mulighederne for og problemerne med at fremstille holocaust i litteraturen. Han tager blandt andet afsæt i en politisk diskussion, som vakte stor opmærksomhed i de tyske medier: den såkaldte Walser-Bubis-debat, som forfatteren Martin Walser i efteråret 1998 udløste med en provokerende tale om tyskernes forhold til deres egen historie. Walsers grundtese i den efterfølgende diskussion med Ignaz Bubis, formanden for det jødiske samfund i Tyskland, var at "vi«ikke endnu havde fundet sproget til at erindre holocaust og nazisternes forbrydelser. Walser kunne således konkludere: "Vi må finde et nyt sprog « ("Kommentar«, p. 20). ${ }^{16}$

Beyer hæfter sig ved tre ting i denne sætning: antagelsen af et fælles "vi«, ideen om »ét« sprog, og den postulerede nødvendighed af at skabe et "nyt« sprog. Ifølge Beyer findes der ikke »ét« sprog, som kan erindre holocaust og nazitiden, og der findes heller ikke et fælles »vi«, som kan definere, hvordan holocaust og nazitiden skal erindres. Og desuden har der altid eksisteret for-

15. Marcel Beyer: "Kommentar. Holocaust. Sprechen«, i: Text und Kritik, Heft 144: „Literatur und Holocaust«, Oktober 1999, (i det følgende forkortet »Kommentar»), p. 22.

16. Talen ved uddelingen af den renommerede fredspris i Frankfurt i efteråret 1998 blev mødt med skarpt kritik af blandt andet Ignaz Bubis, der beskyldte Walser for åndeligt brandstifteri. Diskussionerne rasede derefter i flere uger i tyske aviser, inden det i december 1998 kom til den samtale mellem Bubis og Walser som Beyer tager afsæt i i sit essay. 
skellige måder at erindre og fremstille holocaust på, måder som Walsers udsagn om et »nyt« sprog åbenbart prøver at delegitimere. Med Beyers ord:

»Har der ikke eksisteret mange forskellige måder at tale på, lige siden talen om Holocaust gik i gang? Kan det altså dreje sig om at erstatte »ét» sprog med »ét« andet? Jeg har indtryk af at det »ny« ved det »ene« krævede sprog beror på den antagelse at tidligere måder at tale på mangler gyldighed, og at det nye, projekterede sprog nu skulle kunne garantere en almen gyldighed» (»Kommentar», p. 20, mine udhævninger, M.S).

Heroverfor understreger Beyer at der findes en mangfoldighed af perspektiver på denne historisk begivenhed, der alle har deres forskellige måder at tale om holocaust og nazitiden:

"På baggrund af nationalsocialismen og Holocaust findes der en række meget forskellige måder at tale på, forskellige vanskeligheder ved at tale. Tavsheden over for det oplevede er noget andet end tavsheden over for det begåede. Den tavshed der findes hos dem som ikke længere kan tale, er en anden form for tavshed end tavsheden på grund af viden. Der findes en tavshed på grund af uvidenhed, og der findes en tale der hævder at være uvidende. Tavsheden hos dem som ikke vil fortie noget, står over for tavsheden hos dem der tænker over hvilke vanskeligheder talen kan medføre her« (»Kommentar», p. 19).

At tale om holocaust og nazitiden er med andre ord altid afhængig af talerens baggrund og perspektiv. For eksempel ville den forhenværende værnemagtssoldat Martin Walser nødvendigvis bruge et andet sprog og en anden erindringsform over for de historiske begivenheder end en jødisk overlevende fra Auschwitz. I modsætningen til Walser kræver Beyer derfor ikke »ét sprog «til at erindre holocaust og nazitiden. Beyer understreger snarere at »intet enkeltbidrag, intet enkeltperspektiv kan hævde at være ene om at have gyldighed« (»Kommentar», p. 21). Det gælder snarere om at give plads til de forskellige måder at tale om holocaust og nazitiden på, og at forstå at dokumenter, erfaringer og faktiske begivenheder ikke kan ses uafhængig af perspektivet: fakticitet og det formale perspektiv er ifølge Beyer »fra første færd knyttet til hinanden« (»Kommentar«, p. 21). Med henvisning til Jorge Sempruns gengivelse af dialoger om holocaust skriver Beyer: »Men når talen om holocaust på denne måde uvægerligt bliver et spørgsmål om form og perspektiv, den enkelte talers perspektiv i forhold til andre perspektiver, så fremstår projektet med at finde "ét « sprog desto mere suspekt» (ibid.). Og Beyer fortsætter: »Der er enighed om kendsgerningerne - men 
deraf at ville aflede et konsensussprog og, for litteraturen, en konsensusform og konsensustone, forekommer mig ikke blot at være upassende, men også uværdigt og farligt« (»Kommentar», p. 2lf).

Beyers egen strategi består i "perspektivets præcision«. I stedet for at proklamere et fælles sprog som per definition ikke kan rumme alle forskellige perspektiver og måder at tale på, kræver Beyer "præcisionen, sprogbevidstheden og afkaldet på proklamere og illustrere verdensudkast« (»Kommentar«, p. 23). Den formale udfordring ligger således i et nøjagtigt arbejde med sproget der samtidig skal umuliggøre »grove kategoriseringer og slagord«. Med andre ord: »Perspektivets præcision: det kræver et omfattende, detaljeret arbejde med sproget« (ibid.).

Beyers roman fra 1995 er bygget på denne formale strategi i og med vi udelukkende følger de to personers perspektiver, uden at en alvidende fortællerstemme blander sig. Når Niels Barfoed spørger, hvilken pointe der ligger i at "det diabolske propagandageni Joseph Goebbels aldrig ses eller nævnes i anden rolle end den hengivne fader, « så ligger svaret ikke i, at Beyer vil fremstille et idyllisk nazistisk privatliv, sådan som Barfoed tror. ${ }^{17}$ Beyer prøver snarere at følge Helga Goebbels' blik på de historiske begivenheder. Og det samme skal læseren, der er nødt til at følge pigens barnlige blik på sin far, uden at Beyer griber ind med en alvidende eller moraliserende fortællerstemmes. I et interview sagde Beyer senere om romanen: „Læseren er den moralske instans. Det var vigtigt. Jeg ville naturligvis bedømme. Hele tiden måtte sætninger stryges «. ${ }^{18}$

Ideen om perspektivets præcision er dermed også et forsøg på at inddrage læseren som moralsk instans. Når vi følger Helgas blik på hendes far, er det ikke, som Barfoed mener, for at vise en nazistisk familieidyl, men for gennem Helgas perspektiv at vise de brudflader, hvor den nazistiske familieidyl bliver afsløret som ren propagandaløgn. Skønt Helga ikke selv er i stand til at fælde en moralsk dom, opfatter hun meget nøje de løgne, som de voksne opfinder for at dække over hendes fars talrige affærer med sine sekretærer, mens hendes mor bliver indlagt med forskellige nervesammenbrud. Med Helgas barnlige blik bliver ideen om den sunde tyske familieidyl formentlig slået mere i stykker end i de mange biografier om ægteparret Goebbels' mislykkede familieliv. Men romanen tolker ikke og dømmer ikke.

Det samme gælder i forbindelse med skildringen af det politiske menneske Joseph Goebbels, der ikke, som Barfoed antyder, er fraværende i romanen. Gennem Helgas perspektiv følger vi den formentlig mest berygtede tale

17. Niels Barfoed: "'Jeg hører de søde små stemmer'. Fortænkt, interessant ung tysk roman«, in Politiken, den 22. april 1997.

18. Grauzone, op.cit., p. 14. 
som Goebbels nogensinde holdt: talen om den totale krig i Berliner Sportpalast i 1943. At Barfoed åbenbart ikke har genkendt talen, er formentlig ligeledes begrundet i romanens formale strategi. Ingen steder i romanen bliver det sagt direkte, at Helga overværer netop denne tale. Og læseren følger kun Helgas opfattelse af stemningen i salen, af temperaturen og af tiden - som bliver længere og længere for det barn der kun er til stede som propagandainstrument uden at forstå noget af talens indhold. At det drejer sig om denne berygtede tale, fremgår alligevel af enkelte detaljer som Helga opfatter. Talen bliver dog ikke tolket og ikke engang eksplicit nævnt; Beyer tilbyder snarere læseren et perspektiv på talen fra Februar 1943 ud fra tilskuerrummet med Helgas øjne. ${ }^{19}$

Heller ikke menneskeforsøgene som Karnau deltager i, bliver bedømt udefra. Faktisk bliver de ikke engang objektivt beskrevet i romanen, men kun gengivet gennem Karnaus nøgterne blik. Læseren er således også her nødt til at følge Karnaus perspektiv på og hans besættelse af disse forsøg. På denne måde kan læseren ikke undgå at overtage bødlens perspektiv. Spørgsmålet er med andre ord, som Beyer senere sagde det i et interview, hvor længe læseren følger dette blik, som en slags medvider, inden han eller hun tager afstand fra Karnaus perspektiv og selv begynder at dømme. Og det er præcis denne reaktion som Beyer vil opnå: at læseren tager stilling, at læseren selv bliver talende, som Beyer skrev i en essay om den tyske digter Thomas Kling. ${ }^{20}$

På denne måde skriver Beyer om nazitiden helt uden moralske domme. Kategorier som skyld og umenneskelighed findes ikke i romanen. Men som vi har set, er de to perspektiver dog alligevel tematisk vævet sammen til et helhedsbillede. Og denne indre forbindelse spejler sig også i overgangene mellem de enkelte afsnit, der skiftevis gengiver Helgas og Karnaus perspek-

19. Eksempelvis bliver Goebbels' berygtede udsagn om at de "utyske« og "skadelige« dele af "folkekroppen« koldblodigt skulle afskæres, så det tyske folks organisme kunne leve, udelukkende gengivet gennem Helga, som ikke helt forstår meningen og mest er optaget af temperaturen og stemningen i salen: " $O g$ atter og atter skriger tilhørerne deres ja af fuld hals til svar. Bare skrigeriet ville holde op, det er så frygteligt højt, mine trommehinder er ved at sprænges [...] Gulvet ryster af trampende fødder, arme fægter i luften. Tilhørere springer op på stolene, så at vi børn ikke mere kan se. Far, vil du ikke nok snart blive færdig med din tale, intet menneske kan holde det ud ret meget længere [...] Far siger: Børn, vi alle, børn. Siger han til slut et par ord om os? Hilde kigger på mig, men far mener: Børn af vort folk. Der må være skåret noget væk, med varmt hjerte og koldt hoved. Men mit hoved er varmt. Skrækkeligt varmt. Alt gløder. Trækker vejret dybt. Men det går ikke, her er ikke mere luft. Kun stank og sved. Hvordan kan far dog stadig brøle i den luft: Nu folk« (FH, p. 166f).

20. Marcel Beyer: »Thomas Kling: Haltung«, in: Text und Kritik, Heft 147: »Thomas Kling«, Juli 2000, pp. 70-78 (herefter forkortet »TKHaltung«). I forbindelse med skildringen af menneskeforsøgene sagde Beyer senere: "... jeg beskriver det slet ikke. Det er rent læserarbejde. I romanen bliver der ikke beskrevet nogen operationer på mennesker. Læserarbejdet er omhyggeligt intenderet«, Grauzone, op.cit., p. 14. 
tiv. Beyer genoptager flere gange enkelte ord eller mønstre fra afslutningen af det ene afsnit i starten af det næste. For eksempel slutter et Helga-afsnit med »... nu er der helt mørkt«, inden det følgende Karnau-afsnit begynder med: »Næsten lydløs i mørket ...« $(F H$, p. 38). Intentionen bag denne motivgentagelse bliver blandt andet tydelig i forbindelse med et hyppigt genkommende motiv: de kolde fødder på jorden. Allerede i andet kapitel hvor Karnau første gang møder børnene, bliver Helgas lillesøster Hedda sat i forbindelse med dette motiv, men den tematiske baggrund bliver først tydelig i overgangen fra fjerde til femte kapitel. Her sætter Helga Goebbels fødderne på jorden, efter hun imod sin vilje er blevet båret på armen, hvilket Karnau tolker som en »formning « af børnene. Kapitlet slutter med en antagelse om at hun nu er ligesom et dyr »der klæber til jorden« $(F H$, p. 147). Og det næste kapitel begynder med Karnaus perspektiv, som ser på KZ-fangen, hvis kropssved får hans fødder »til at klæbe fast på gulvet« $(F H$, p. 151). På tysk bruger Beyer i begge tilfælde ordet »Boden« $(F$, p. 149; FH, p. 153). Derved forbinder han den voksnes formning af barnet med Karnaus menneskeforsøg. På en lignende måde slutter det tredje kapitel med Karnaus optagelser af døende soldater og hans begejstring over de vellykkede optagelser med ordene: "Hvilken begivenhed. Hvilket panorama» $(F H$, p. 114). Næste kapitel starter med Helga som står i bjergene og tænker: »Hvilket panorama» $(F H$, p. 117).

Dette formale princip kan bedst tolkes med afsæt i dub-tekniken, som Beyer, der samtidig arbejder som musik-kritikker, tydeligvis er inspireret af. Thomas Schmidt forklarer: »Dub-musik er elektronisk bearbejdet, den baserer sig på et materiale der er sønderdelt ved en mixerpult, og som kombineres med et andet materiale, ældre eller nyere. Dermed bliver originalens rytme bevaret og krydset med en anden song. Begge klangverdener fastholdes, allusioner og historiske henvisninger, dvs. litterære teknikker, breder sig ind i popmusikken. $\|^{21}$ Beyers formale strategi læner sig op ad dette princip: romanens to perspektiver smeltes ikke sammen, men står alligevel i forbindelse med hinanden: trods deres indbyrdes forskellighed er de i konstant vekselvirkning, i kraft af de formale og semantiske henvisninger.

\section{III.}

Men Beyers intention om, at læseren skal blive til den moralske instans, skal ikke kun læses som en formal strategi. Den kan også læses ud fra en litteraturhistorisk synsvinkel. Allerede Thomas Thurah spørger: „Hvad kan en

21. Schmidt op.cit., p. 145. 
godt 30-årig tysk forfatter sige om nazitiden, som Günter Grass, Heinrich Böll og Siegfried Lenz ikke allerede har sagt meget bedre?« Thurahs egne konklusioner er, kort sagt, at der ikke er særlig meget nyt i Beyers roman. Ifølge Thurah handler romanen om det gode mod det onde, om frit og ufrit, så der ikke er meget andet tilbage end "moraliserende almindeligheder». Beyers »humanistisk sindede [...] roman« ligner derfor i mange henseender »Grass-Böll-Lenz-traditionen«. ${ }^{22}$

Jeg mener tværtimod at Beyers roman kan læses som et egentligt opgør mod den litterære traditionslinie som Thurah prøver at skrive ham ind i. Forskellen mellem Beyer og hans forældres generation ligger i Beyers sprogopfattelse, som tydeligvis er påvirket af den franske poststrukturalisme. Sproget kan for Beyer aldrig adskilles fra det enkelte menneskes sprogbrug og er dermed altid forbundet med magt og med sprogets totalitære funktion. Og det gælder også for litteraturen. Beyer diskuterer blandt andet sprogets forhold til læseren i essayet om digteren Thomas Kling, hvor han også placerer sin egen formale strategi i forhold til den litteraturhistoriske udvikling i den tyske efterkrigslitteratur. Også denne gang tager han udgangspunkt i nazitiden i og med han tolker et digt af Kling, der beskæftiger sig med Joseph Goebbels sprogbrug og hans retoriske brug af den »op- og nedsusende pegefinger«i talen fra 1943.

Beyer starter diskussionen med at henvise til den etymologiske baggrund for ordet »digter«. »Digter« afledes ifølge Beyer ikke fra »condensare«, som mange mener, men stammer oprindeligt fra »dictare«. Dermed er digteren i familie med diktatoren: „Ordhistorisk deler digteren oprindelse med diktatoren, begge begreber har udviklet sig fra »dictare«, hvis betydningsfelt omfatter at tale forstået som instruktion og forførelse, så vel som at tale forstået som at diktere til pennen, altså talen ved overgangen til skriften.» Beyer konkluderer: »Digter og diktator: begge er talere, fortalere, indgydere« (»TKHaltung«, p. 70).

Det litterære sprog er således ikke uskyldigt, men står altid og nødvendigvis i forbindelse med forsøget på at overtale og at instruere tilhøreren. Heller ikke litteraturen kan adskilles fra den magtudøvelse, som al sprogbrug er underlagt. Nazisternes propaganda er i denne forbindelse kun den ultimative magtudøvelse gennem sproget. Joseph Goebbels, den person som Beyer altid vender tilbage til, er i denne forbindelse inkarnationen af den lige så umenneskelige som mesterlige brug af sprogets retoriske midler.

22. Problemet med Thurahs tolkning er at han ukritisk overtager Karnaus blik på barnet, så at han kan skrive: "til gengæld for den voksnes forråelse idealiseres barnet«. Beyers kritiske intention - der ikke idealiserer barnet, men diagnosticerer Karnaus idealistiske blik på barnet $\mathrm{og}$ hans søgen efter det autentiske i barnet som potentielt farligt - bliver overset. 
I sin tekst om Thomas Kling benytter Beyer denne tætte forbindelse mellem digteren og diktatoren til en karakteristik af to hovedstrømninger i den tyske efterkrigslitteratur, der begge tolkes som en reaktion på nazisternes totalitære sprogbrug. Det første reaktionsmønster forbinder Beyer med lyrikeren Gottfried Benn og hans monologiske digtning. Ifølge Benn følger digteren kun en indre stemme, som ikke er henvendt til nogen læser; lyrikken skal ikke læses op. I den programmatiske tale »Lyrikkens problemer« fra 1951 skriver Benn, at »digte ikke er rettet til nogen«, ${ }^{23}$ digteren »følger en indre stemme som ingen hører $",{ }^{24}$ og det »absolutte digt« er »uden tro, håb og adresse «. ${ }^{25}$ Kort sagt: der er tale om digte »hvis monologiske karakter ikke kan betvivles«. ${ }^{26}$ Ifølge Beyer kan den monologiske digtning læses som et forsøg at opløse den tætte forbindelse mellem digteren og diktatoren: "En indre instans hvisker til digteren, men digteren hvisker ikke til nogen - spørgsmålet om hvordan man skal omgås slægtskabet mellem digter og diktator har allerede løst sig selv« (»TKHaltung«, p. 72).

Det andet reaktionsmønster finder Beyer i den moralske og realistiske litteratur, der er blevet dominerende siden 60'erne, og som vender sig imod Benn og hans formalisme. Den nye generation reagerede således på erfaringen af, at sproget i nazitiden blev brugt totalitært, ikke ved »tilbagetrækningen til Jeget« ligesom Benn, der politisk først har støttet nazitiden og siden med sin indre emigration de facto tolererede den, men med negationen af retoriske og formale midler: „Den der forstår 'tilbagetrækningen til Jeget' som en fortsættelse af den 'indre emigration' der gjorde at man tålte nationalsocialismen, og den der ydermere stadig kan høre lyden af 'Fører-oderne', hvis forfattere blev hædret med priser også i 50'ernes Vesttyskland, - han kan komme til at indtage en position hvor man forsøger at modvirke faren for propaganda ved at reducere de formale aspekter« (»TKHaltung«, p. 72f).

I modsætning til Benn har disse forfattere - implicit mener Beyer 68'ergenerationen - en intention om vat lade stilen rykke i baggrunden til gunst for substansen« (»TKHaltung«, p. 73). Hvor Benn proklamerede formens primat, kan der nu tales om indholdets primat, der negerer formen og retorikken. I stedet for at bruge formen og retorikkens virkemidler bliver »den litterære teksts 'kunstløshed' til signal på autenticitet« (ibid.). Med andre ord: »Jo mindre grad af iscenesættelse af det poetiske sprog på skrift og i foredrag, desto længere rykker digter og diktator fra hinanden« (ibid.).

23. Gottfried Benn: »Lyrikkens problemer«, in: Gottfried Benn: Glasblaseren og andre Essays. På dansk ved Jørgen Elbek, udvalg og indledning ved Thorkild Bjørnvig. København 1964, pp. 137-164, her p. 143.

24. Ibid., p. 153.

25. Ibid., p. 159.

26. Ibid., p. 162. 
I modsætning til disse opfattelser kræver Beyer en bevidst iscenesættelse af sproget og ikke mindst en bevidst iscenesættelse af sprogbrugen hos andre mennesker der anvender sproget retorisk. Det gælder ifølge Beyer ikke om at erstatte »den iscenesatte tale med 'autentisk tale" ", men om at konfrontere autenticitetskravet og misbrugen af sproget med en bevidst iscenesat sprogholdning. Denne venden sig bort fra autenticitetskravet sidestiller Beyer med en afvisning af den monologiske kunst: "Lige så lidt er der tale om en tilbagetrækning til monologens position. At det at tale foran et publikum er forbundet med magt, bliver ikke ignoreret, men derimod tematiseret« (»TKHaltung«, p. 77).

Beyers forestilling om »perspektivets præcision« kan med andre ord læses som en konkret litteraturpolitisk strategi. Når al sprogbrug står i forbindelse med en totalitær propaganda, er det klart at Beyer må prøve at finde en litterær form i hvilken det er tilhøreren der bliver stimuleret til »selv at blive den talende« (ibid.). Det gælder med andre ord om at skabe »en sprogholdning som ikke er forbundet med en hensigt om at få det sidste ord, om at gøre tilhøreren mundlam«(ibid.). Beyers venden sig bort fra forældregenerationens moraliserende litteratursyn sker på denne baggrund. Hans kritik er radikal. Så længe deres egen sprogbrug ikke er reflekteret, kan deres moralske intentioner ifølge Beyer selv blive til en totalitær gøre læseren mundlam. I teksten om Thomas Kling antyder Beyer »at der den dag i dag findes forfattere der, skønt de umisforståeligt har kritiseret den sprogholdning der har inkarneret sig i Joseph Goebbels' måde at tale på, ikke har slettet den 'op- og nedsusende’ pegefinger fra deres repertoire af gestus. (»TKHaltung», p. 78).

Beyers roman kan læses som en reaktion på denne erkendelse. Beyer søger med sin forestilling om "perspektivets præcision« at finde nye formale udtryksmåder hinsides de foreliggende litterære traditioner. Men også de sprogteoretiske overvejelser og Beyers fremstilling af Karnaus diabolske søgen efter autenticitet kan læses i denne litteraturhistoriske dimension. På den ene side rummer romanen en kritik af den totalitære sprogbrug, Goebbels' menneskeforagtende propaganda, der tillige kombineres med medieteoretiske overvejelser. På den anden side bliver Karnaus søgen efter oprindelighed og autenticitet dechifreret som farlig. Det er denne længsel, som får Karnau til at hjælpe med at ensrette mennesker og formentlig ender med at gøre ham til morder. Implicit retter romanen altså en skarp kritik mod 68'ernes negation af formen og deres - ifølge Beyer ureflekterede søgen efter »varm menneskelighed «. ${ }^{27}$

Titlens »Flyvende Hunde« kan forstås på denne baggrund. Flyvende hunde er en slags flagermus der er stærkt lydfølsomme. De kan med andre ord ikke ensrettes gennem den totalitære sprogbrug. Men desuden underminerer de Karnaus forsøg på at bestemme menneskets væsen ved hjælp af 
optagelserne af stemmen og lydene. I en samtale erfarer Karnau således, at »flagermus på grund af deres gode ører får andel i en verden, der forbliver lukket for os mennesker« $(F H$, p. 175f). Og dette gælder i en vis grad også de flyvende hunde, som opfanger frekvenser i den menneskelige stemme, »der ikke spiller nogen rolle for os, da vi ikke opfanger dem med øret« $(F H$, p. 176). Flyvende hunde er således et bevis for at lydenes verden »er langt større, end vi kan forestille os«, og at der findes »nuanceringer i menneskestemmen, som et menneske aldrig kan høre« (FH, p. 176). Karnaus forsøg på at kortlægge menneskets stemme er således blevet meningsløst:

"Og lige med ét smuldrer stemmens landkort mellem hænderne på mig, de indtegnede linier leder i en forkert retning, har altid gjort det, pludselig er hele kortet atter hvidt og tomt, alle tegninger forsvinder [...], alt forsvinder fra mit indre øre, alt bliver suget tilbage til stilheden ved synet af denne aldrig hørbare tone i den verden, som kun dyrene kender« $(F H$, p. 176f).

Forsøget på at definere hvad menneskene er, er blevet umuligt: mangfoldigheden af stemmer, lyde og nuancer kan aldrig samles eller forstås; stemmens hemmelighed er uransagelig.

\section{IV.}

Beyers succes er, kan man formode, ikke kun begrundet i hans sprogteoretiske overvejelser eller den tæt komponerede formale opbygning af romanen. Den skal snarere ses i forbindelse med den litteraturhistoriske situation, som Beyer står i. Hans roman kan læses som et konkret og eksemplarisk opgør mod både formale kategorier og indholdsaspekter, der indtil 90'erne har været dominerende i den tyske efterkrigslitteratur.

Man har i denne sammenhæng flere gange antaget, at den yngre generation af forfattere bevidst vender sig imod den forrige generations politiske og moralske intentioner. De unge forfattere, siges det, interesserer sig snarere ukritisk for formen og æsteticismen. I den nuværende Tyskland, skriver eksempelvis den østrigske digter Franz Joseph Czernin kritisk, hylder man i stedet for Brechts epigoner »endnu en gang Benns epigoner «. ${ }^{28}$ Også Thomas

27. Med henvisning til den litterære udvikling i Vesttyskland efter 1945 skriver Beyer ironisk: "Hvor 'menneskeligheden' hersker, synes der ikke at være behov for at stille flere spørgsmål - som om ikke også den nationalsocialistiske litteraturproduktion havde forsvaret sin egen forestilling om et 'positivt menneskebillede', som om den nogensinde havde fornægtet 'den menneskelige varme' eller 'ægte kammeratskab' ", "Kommentar», p. 22. 
Thurah antyder i forbindelse med Beyers roman at Beyer »og dele af hans generation af europæiske forfattere« ikke forstår krigen og nazitiden »som et moralsk og politisk forklaringsproblem«, men udelukkende som en »uomgængelig forhistorie og nye historiers matrice ${ }^{29}$

Min læsning af romanen og af Beyers essays modsiger den slags antagelser. Skønt Beyer ikke gør brug af en alvidende og moraliserende fortællerstemme, tager han ikke afstand fra de kritiske og moralske intentioner. Hans formale strategi («perspektivets præcision«) er snarere båret af et klart politisk og moralsk engagement. I teksten om Thomas Kling skriver Beyer: „Form, sådan kunne man sige det, bliver erkendt som en højst politisk størrelse - men i stedet for så at tilbagevise formen, bliver den anvendt« (»TKHaltung«, p. 77).

Beyers undertiden voldsomme kritik af forældregenerationen kan således ikke tolkes som en apolitisk modreaktion eller som en given sig hen til den postmoderne leg med sprogets byggeklodser. Man kan snarere iagttage en grundlæggende ambivalens hos Beyer i forholdet til den forrige generation; for at sige det kort: en blanding af politisk affinitet og formmæssig distance. Beyer holder med andre ord fast i de kritiske og politiske intentioner der var fremherskende i forældregenerationen; men han retter samtidig en voldsom kritik mod deres ideologiske tro på nogle ganske vist humanistiske, men også fastlagte meningssystemer som der ikke blev stillet spørgsmålstegn ved, og som derfor kan opleves som totalitære..$^{30}$ Imod en sådan dogmatisk og til tider totalitær sprogbrug peger Beyer på sin egen litterære intention: „Det gælder om ikke at lade det blive ved det almene, men uafladeligt at stille spørgsmål til sin egen sprogbrug og i det mindste se det som en mulighed at ens eget toneleje er tvivlsomt« (»Kommentar«, p. 23).

28. Franz Josef Czernin: „Falten und Fallen. Zu einem Gedichtband von Durs Grünbein«, in Schreibheft, Zeitschrift für Literatur 45, maj 1995.

29. Thurah, op.cit.

30. Det vil være frugtbart i denne sammenhæng også at undersøge den nye generations forhold til Gottfried Benn. Der vil formentligt kunne observeres den samme ambivalens med andre fortegn. Således er ikke kun Beyer, men også andre forfattere stærkt påvirket af Benn, men afviser samtidig eksplicit hans formalisme og æsteticisme. Eksempelvis siger Durs Grünbein, der flere gange er blevet udnævnt til »den anden Benn« og den »Benn'ske hjernehund«, $i$ et interview om hans forhold til Gottfried Benn med henvisning til Osip Mandelstams dialogiske litteraturopfattelse: »Men jeg håber nu at fremtiden tilhører Mandelstam og ikke Benn", "Gottfried Benn schmort in der Hölle. Ein Gespräch mit dem Dichter Durs Grünbein über das Paradies, die Apokalypse und den wahren Ort der Poesie«, in Der Tagesspiegel, den 4. August 2001; se også Beyer: »TKHaltung«, p. 77. 